\title{
Moral Values of Javanese Leader in Serat Wedhatama
}

\author{
Sudrajat $^{1}$, Djoko Suryo ${ }^{1}, \&$ Dwi Siswoyo ${ }^{1}$ \\ ${ }^{1}$ Postgraduate Program of Yogyakarta State University, Yogyakarta, Indonesia \\ Correspondence: Sudrajat, Postgraduate Program of Yogyakarta State University, Karangmalang, Depok Sleman, \\ Yogyakarta Special Region, 55281, Indonesia. E-mail: sudrajat@uny.ac.id
}

Received: December 22, 2017

doi:10.5539/ass.v14n3p49

\author{
Accepted: January 16, $2018 \quad$ Online Published: February 26, 2018 \\ URL: https://doi.org/10.5539/ass.v14n3p49
}

\begin{abstract}
This study aims to seek moral values of leadership in the Javanese culture derive from Serat Wedhatama (Wedhatama Script) by Mangkunagara IV. The Indonesian local wisdom of literary works was intellectual asset must be explore and transform in the daily life in order to realize prosperous of Indonesian society. This research used philosophical research method in which of Serat Wedhatama by Mangkunagara IV as a primary data source. The technique of data analysis used hermeneutical method with three procedure: verstehen, interpretation, and hermeneutik. The results showed that the moral values in Serat Wedhatama work of Mangkunagara IV consist of the value of courage (satriya), simplicity (prasaja), the kindness (setya budya), sincerity, and the religious values. Panembahan Senapati is the ideal Javanese leader who succeeds bringing happiness and prosperity to all Javanese people. The implementation of leadership based on these moral values by Mangkunagara IV succeed brought prosperous for Mangkunegaran people.
\end{abstract}

Keywords: Serat Wedhatama, Mangkunagara IV, Javanese leader

\section{Introduction}

Indonesia has a complex problem with regard to ethics and morality such as criminality, violence, drug abuse, and corruption which show no sign of ending. Many leaders and officials are involved in the practice of corruption, collusion, nepotism, and manipulation. Executives and legislatures even collectively commit corrupt acts, plundering state money for personal gain. People's representatives only promised beautiful promises during the election campaign, but forgot after being elected. Most of the people's representatives are concerned only with self-interest and their party, seeking to perpetuate their position regardless of the fate and prosperity of the people it represents. Bertens (2004: 33) states that members of the Indonesian House of Representatives who should be vicious eradication symptom of corruption, apparently themselves have been infected with the national disease. They had fellowshipped with enemies who were supposed to be fought bitterly.

Establishing ad hoc commission to combat corruption called Commission of Corruption's Eradication (KPK) have not been successful. Corruption, crime, violence, and murderer become inexhaustible news in the Indonesian mass media. This phenomenon similar to the condition in the mid-nineteenth century where social deviations occured massively in Indonesia, especially in Java. The poverty that hit Java's rural area encouraged criminal acts such as theft, robbery, murder, and violence. Furthermore, monetization encourages the middle class and the Javanese aristocrats to become consumerists. Luxury goods such as: vehicles, clothing, and home furnishings became a pride for the Javanese aristocrats to show their true identity as the ruling class. Opium, concubine, gambling, and prostitution are also symptoms that reinforce the occurrence of cultural deviations so that the poet Ranggawarsita called it as "a crazy era". Furthermore, in the field of politics, traditional elite has alienated the role and authority where they must comply and obey the will of the colonial government as the guarantor of the king's power.The inability of traditional Javanese leaders in carrying out their roles and duties has inspired the idea and thought of the Javanese nobility to improve the leadership qualities of the kingdom.

These conditions inspired the ideas, notions, and thinking of the nobles and poets to find out the best ways to improve Javanese leaders conditions. Yasadipura I, a poet of Surakarta Palace proposes a theory of leadership called Astabrata. He argued that the king should be able to carry out his duties and responsibilities if they hold the teachings of the "Eight-behavior" (Astabrata). Moertono (1985: 52) suggests that the kings should have moral, values, and characters of the "eight-guardians of the wind-direction" or astalokapala namely Indra (benefactor), Yama (combating evil), Surya (wise), Candra (merciful), Bayu (meticulous), Kuwera (entertaining), 
Baruna (smart), and Brama (brave). Another kings and Javanese philosopher who taught the virtue and morality is Mangkunagara IV. He was a bright king that carry out Mangkunegaran kingdom to the peace, welfare and prosperity era in nineteenth century. His succed for developing economy by establishing plants and industries, especially sugar industries, shown his capacity as the Javanesse great king. In addition, he has great ideas to define the highly-valued literary and cultural works such as: Serat Wedhatama, Tripama, Yogatama, Paraminta, Paliwara, and so on (Siswokartono, 2006).

Serat Wedhatama was the famous literary work contains principles, guidance, and advice about the goodness. Its quoted in everyday life conversation, especially for Javanese villager who appropriate traditional Javanese moral values. It poem interpreted as a doctrine of wisdom, psychological mind, character, and soul for Javanese nobleman to be an ultimate human being. "Serat" was script, "wedha" means kawruh, knowledge, science or principles, while "tama" means primary, good, noble and perfect (Sumantri, 2005: 35). Serat Wedhatama written in the form of Javanese song, a style of Javanese poetry called macapat. Its have highly soul of religious thrill heart, so the values and teachings easily understood. It will be very different results if we just reading, not only misunderstanding of meaning but also vacuous of soul and spirit. Its literary works encourage moral values acknoledgement within Javanese human being when read and sung in the traditional ceremony.

The Javanese society regulates interactions by two main principles: harmony and respect. It was not only forbids Javanese human doing on the basis of his own interest, but also cares others in order develop harmony in society (Endraswara, 2010: 14). The principle of harmony prohibits someone take positions causes conflict with others. Its placed as ultimate regulation, preceding a positive law binding the power and ethical implications demands individuals to maintain good relations with others in order to develop order and harmony in society. The Javanese have principle that nature and life was relative uncertain. Relativism of the Javanese understood that the truth as something uncertain has a relative nature, except the truth of God, the creature of universe (Santoso, 2012: 19). The concept of power in Javanese culture rooted on Hindhu cosmology emphasizes harmony between macrocosm (the God world) and microcosmos (the Human world). Humans were under influence supranatural forces sourced in the direction of wind, stars, and planets. These forces not only produce prosperity but also destruction for nature. Harmony between the kingdom (microcosm) and the universe (macrocosm) acomplished by arranging kingdom as universe at the miniature (Soeratman, 2000: 2). The leaders overwhelming duty for create synchronization between micro and macrocosm, so appropriate for the great powers and sovereignty. As the representative of God (khalifatullah) who knows exactly what to do, the king get knowledge and revelation from the God, consequently his decisions can not denied by anyone (Ali, 1986: 27). While having the great privileges and powers, the king has a substantial duties and obligations commonly referred as dharma. The main mission was carry out harmony and balance to reach a prosperous, peaceful, and wealthy. The enormous power of the king expected provide great space and authority in order compeling peace and wealthy. The doctrine of virtue about the moral values of leadership in Serat Wedhatama, expected to be a lighter change in Indonesian political life. Leaders become important agent of change in organizations since they are in the best position to facilitate cultural changes (Yusof, Kadir \& Mahfar, 2014). So, revitalization of moral values of leadership in the society by inculcation and internalization expected as long as enlightenment for the civilization and increasing the quality of leadership within Indonesian political institutions.

\section{Methodology}

This research used philosophical research method that seeks to find facts with appropriate and systematic interpretation of cultural structure or philosophical thinking. The Qualitative research are relevant to reveal the meaningfulness data in a philosophical, theoretical, and cultural domain (Muhadjir, 1996: 159). The research data source is Serat Wedhatama consists of 100 verses collection of Reksopustaka library, Surakarta, Indonesia.

Data collecting techniques was done by reading symbolic and semantic levels, recording, and codifying data. Data analysis techniques were performed with verstehen, interpretation, and hermeneutics. The researchers used historical approach to explain history, social, and cultural background of Mangkunagara IV's ideas about primal Javanesse leaders.

\section{Finding and Discussion}

\subsection{The Ideal Leader}

The ideal leader according to Serat Wedhatama is a someone ables to create happiness, prosperity, and peacefull for all human-being (amemangun karyenak tyasing sasama) as the embodiment of the Javanese worldview adorned the world with kindness and beauty (hamemayu hayuning bawana). The ability of leader to conduct of duty (dharma) determined by his ability to cultivate inner ability through live as an ascetic (samadi) therefore strong personality who has divine character. Panembahan Senapati, the founder of the Islamic Mataram dynasty 
in Yogyakarta, was a historical figure identify as the ideal Javanese leader. He was a satriya who have capability to reducing the desire of the world to develop inward through the path of ascetic or meditation in a lonely places. In addition, he was able to control the ruler of the Queen of the South (Ratu Kidul) and Mount of Merapi (Gunung Merapi) help maintaining peace and political stability in Mataram.The unity between Panembahan Senapati and Queen of South (Ratu Kidul) was an expression of the king's power not only in power on the visible world, but also in power over the invisible world. In Serat Wedhatama, Mangkunagara IV state in follow:

Exemplifies the main behavior, for the Javanese, the Great Man in Mataram, Panembahan Senapati, who sincerely, reducing the lust, with concern, day and night, developing the pleasure for all human-being (Mangadeg Foundation, 2010: 6).

The way to building of peace for all human-beings can be done by promoting harmonious, balance, and peaceful without disputes, and help each other (anawur gawe enaking atining sapada). The next ways is building agreement through appreciate and honor with others characterized by a manner of speaking and self-giving shows respect according to position and degree in Javanese social structure (Suseno 1985: 60).

The ideal of Javanese leader is someone have great power to alienate conflicts by reducing contradiction interests in society. The ways are building values and norms of behavior aimed to preventing the emergence of emotions and conflicts. Through these values and norms would emerge character of love (tresna) that consider from the way of speaking and careful (ngati-ati). Building and creating happiness, delight, and well-being is the main duty (dharma) of leaders. The idea Mangkunagara IV represents an ideal leadersnot only capable for developing harmony, welfare, and salvation but also avoiding possibility of disturbances, conflicts and frictions.The Javanese peoples share assumption that ideal king is someone who controls infinite power and reflects the spirit of God (Hyang Suksma Kawekas), he is also supposed to control his personal will. The king is intermediary who has power to organize relationship between human and human, human with their God, and human with nature (Moertono, 1985: 49).

In the Javanese culture, the king is the center of micro cosmos which occupy the top of hierarchy in the stratification of social status, and leading all humankind. The king regarded as God (in the time of Indonesian Hindu Buddhist kingdoms) and as representative of God (khalifatullah in the era of the Islamic kingdom). He became medium or intermediary between the microcosm and the macrocosm. Therefore, the king has important role in order to maintaining, preserving, and protecting the kingdom. Herusatoto (2008: 133) states that attitude of the Javanese leader called religious knight (satriya pinandhita) which not depend on treasure (arta), degrees (derajat), power (kramat), and and sovereign (kuasa). The ideal leader has passionate attitude, selflessness, rich without property (sugih tanpa banda), and to be winner without humiliate (menang tanpa ngasorake). Mangkunagara IV states that the leader must have three things: the noble descendants (wirya), the treasures (arta), and the cleverness (winasis) in order to be an ideal leader (Mangadeg Foundation, 2010). These three aspects are basic capital for the king implementing duty in order achieve degree of the great king (ratu gung binathara).

\subsection{Moral Values of Javanese Leaders}

Serat Wedhatama recommends the Javanese leaders having policies and behaviors based on dignified values. Leader must have moral values: courage (satriya), simple (prasaja), sincere (rila), nobility (setya budya), and religiosity (agama ageming aji). The leader possesses these moral values is primal leader not only enable to destroy the evil (angkara) and evil desires to demolish the order of human life, but also developing happiness and prosperity for all human-kind.

The leaders regarded as satriya by two indicators: the first holy or clean personality, and the second possesion high dedication to their kingdom (Endraswara, 2013: 87). The leaders must liberate herself from personal motivations to be fair to all people. The courage of Mangkunagara IV shows in the case of taking over the royal lands of kingdom for the sake of the country's economy. The nature of satriya also indicate by her decision to fight against Prince Dipanagara (1825-1830) considered to destroy order and cause misery for Javanese (Siswokartono, 2006: 81). The satriya does not dependent others in taking policy or accepting the consequences. The courageous and unrely to others are the main personality of Javanese satriya. Mangkunagara IV states it in Serat Wedhatama (1:7) as follows:

His fortitude so trivial, finally relying on his father and mother, the esteemed and the noble descendants, is that your father, while you are hang outnot yet alone, do not understand the etiquette, which is the main of religious teaching (Mangadeg Foundation, 2010: 3).

Courages was a strong ethical outlook dealing problems based on truth and justice. The dare properly was high 
ethical morality indicate the virtue of leader. In the view of Seneca (Suseno, 1998: 64) the brave people do not just overcome the feelings of fear, but unrecognize the feelings of fear. He refuses to surrender over the threats and tried to broke. Whatever threatens will be confronted he stand facing with calm, shows the unanimity of the leadership soul to uncapitulate to external threaten. Satriya is terminology for people who have inner determination manifested in positive attitudes: honest, not easily swayed by the circumstances surrounding, not dragged into the flow of bad habits such as corruption, collusion, and other habits that violate ethics and morality. Satriya was dare doing right in the midst of people who have been carried away by the unhealthy stream of life (Chodjim, 2016: 127).

In fact, it been blessed God, returning to empty world, unworldly drunkenness, whose nature master-power, back to origin ... (Mangadeg Foundation, 2010: 15).

The second moral value taught by Mangkunagara IV is simple attitude and lifestyle (prasaja). Simplicity is one of the Javanese attitudes that view life as an effort to fulfill their minimal needs, not exaggeration, and to see inner happiness as the ultimate goal. Simple life is representation of Javanese culture does not pursue worldly pleasures, simply life, honest in doing the job, and full of commitment. The simple attitude of a leader is produce of his perseverance in inner that no longer dazzle by the glitter of worldly possessions, prefers to enjoy the inner clarity to bring happiness and prosperity. One of moral values of simplicity is avoiding arrogant. The Javanese language recognizes some terminology, namely: adigang, adigung, and adiguna. Arrogant caused by relying on position, rank, or degree called adigang. Its brings to badness for leader and invites contempt from others. Excessive self-belief ability to cultivate is excessive arrogance that is self-forgetful and does not attention on shortcomings and weaknesses. Adigung is an arrogant character causes relying on intelligence and cleverness of one-self so underestimate another people who are just to cover up his stupid state and have no advantages. Adiguna is an arrogant character for relying on courage and cleverness in tongues (Herusatoto, 2008: 146).

The third moral value teaching of Mangkunagara IV is nobility (setya budya) based on esoteric knowledge about the nature of something or ngelmu. The dignified spirit is character of satriya foster attitude of humility, respect for others, and fair to all people. Serat Wedhatama (5:13 and 3:1) writes as follows:

The famous noble man is, when it can adapt to the circumstances, it is the bud, which will grow on the principal deeds, even though his opinion is true, will still appreciate when there are different opinions.

The science can be realized by behavior, begins with the will, the will means tranquil, good mind of destroyer the evil. (Mangadeg Foundation, 2010: 13)

Goodness based on ngelmu encourages people to ethical-morally doing something. Virtue is a fixed tendency; a disposition keeps that the will fixed in certain direction. Chodjim (2016: 190) states that the leader who is spiritually virtuous always steadfast, not worried, and not tossed around by changing circumstances. Constancy in the face of distractions and temptations will actually establish itself as a person who has real tranquil. Human being who is able defeat the evil will be a forgiving person because realizes that everyone has the possibility doing wrong. Persons will be a dignified spirit when making themselves humble as manifestation of their responsibility of soul.

The fourth moral value is sincere, willing, acceptance of destiny has been determined by God. The sincere leader allow act equitably because has no interest for policy. Sincere value mentioned in Serat Wedhatama (3: 11) as follows:

Shame if, losing without dissatisfied, accepting if gets unpleasant behavior, hatred from fellow, and surrendering all to God (Mangadeg Foundation, 2010: 15).

Willing (rila) is basic attitude of Javanese in order to developing harmony in the world. Its depart from assumption that everything to be and attached to human being as deposit, then any time taken by the owner must be willing to release. It is contained tolerance and patience deal with others who even hurt or harm. For the small people (kawula), it is expressed by eagerness to serve and carry out their leader (priyayi). They become conscious it has destiny for the small people to doing to, work to, and serve the leader. Everything is destiny by the will of God, and must be accepted with sincerity and uncomplaining because basically human must to accredit his own destiny.

The Javanese appreciate one's ability to conceal the circumstances of those who are actually suffering. Commonly, techniques used by the Javanese are habit of pretending or ethok-ethok. Its attempt to keep the level of intimacy, a warmth relationships in which all the exact outlook can be effectively hidden (Suseno 1985: 43). Sincere makes people as the main creature, complete admission of defeat in life, an attitude surrendering to God. In the Javanese culture was called to look at oneself (mulat sarira) and look himself (hangarasa). Sincere will 
not affect disappointment in the life even vice versa, and will convey someone to get closer association with the God (Chodjim, 2016: 241).

The fifth moral value is religiosity by carrying out the behavior the four worship (catur sembah) that is: the bodily worship (sembah raga), the mind worship (sembah kalbu), the spiritual worship (sembah jiwa), and the sense worship (sembah rasa). Serat Wedhatama (4: 1) stated as follows:

Now I say, four prayers (inherit) to be imitated, first: body, creation, soul, and sense, of my son, there when they are achieved, a sign of God's grace (Mangadeg Foundation, 2010: 17)

The teaching of four worship basically a teaching of mysticism or tasawuf. It is a philosophically life meant as the way to improve a human soul through certain religious rituals and practices. Through a mystical religious experience human being tries to get a closer and unify with his God (manunggaling kawula-gusti). The religious experience means an awareness of the unseen world, spiritual or spiritual, as the worldview and the proof of spiritual facts in the physical world. It becomes a reference for describing the unseen reality as a world or spiritual worldview whereby man deals with his fellowman (Daryono, 2007: 126). Through the behavior or ritual of "tapa brata" as attitude askesis one can find a sense that can be made as way of life, guide for will and behavior of human being. The conduct and rituals performed by the Javanese to find the exactly truth called "the religion of sense".

Sumantri (2005: 58) states that for Javanese, sense is a central part the meaning of all the genuine norms as a standard to be obey. It has an important role not only as a feeling, emotion, or human response receiving sensory stimuli such as: bitter, sweet, and salty but also the deepest nature, delight or charm, as the "holy voice" of the nature divine. Sense likened to conscience, the core of the deepest norm, the standard to be obeyed, as a regulator in performing religious, legal, or aesthetic actions. Sense is associated with life despite human being has no sense being an old man, who is considered as a useless man, no taste, and wasted (sepa lir sepah samun). Daryono (2007: 130) state that the purpose of sense is eliminate the misery of life (supadi nir ing sangsaya) and passion of human hearts (mbengkas kahardaning driya). It is right for anyone who wants, and the willing to empower or develop through four worship (catur sembah). Leaders who are enabling a genuine sense will be able to act reminiscent of God who is able bring goodness and well-being of life in the world. He acts in the name of Deity with a mission to control the world for life going should be.

\section{Conclusion}

The teaching of leadership in Serat Wedhatama represent the concept of Javanese power emphasizes rights of king's power to govern life and obligations to bring peace and prosperity. Mangkunagara IV taught that leader does not have to rely on his life, but must be able to bring happiness and inner welfare. To enable performing their duty, leaders should base their behavior and policy on moral values that have the courage (satriya), simplicity (prasaja), nobility (setya budya), sincere (rela), and religiosity. Panembahan Senapati is ideal example, a leader who is seeks to control his passions to pursue inner happiness. He always take ascetic ways (samadi), going in the lonely places to develop the inner cultivate the spiritual aspect.

The findings provide an additional leadership models relevant to Javanese traditions and culture. The moral values leadership taught by Mangkunagara IV in Serat Wedhatama emphasize that the great authority and power of a leader must be balanced by the virtues of noble to not abuse. The values of courage (satriya), nobility (setya budya), simplicity (prasaja), sincerity (rila), and religiosity values are the basic of Javanese culture that emphasizes harmony and togetherness. Political elites expected understand that they have hard duty to realizing prosperity and happiness for all. In addition, they are expected to act and behave ethically in order to realize a just, peaceful and prosperous life.

\section{References}

Ali, F. (1986). The reflection of Javanese power in modern Indonesia. Jakarta: Gramedia Pustaka Utama.

Bertens, K. (2004). The moral sketch: 50 essays of actual problems. Yogyakarta: Kanisius Publisher.

Chodjim, A. (2016). Serat Wedhatama for our time. South Tangerang: Bentara Aksara Cahaya Publisher.

Endraswara, S. (2010). Javanese ethics: ethical guidelines for daily life. Yogyakarta: Narasi Publisher.

Endraswara, S. (2013). The philosophy of Javanese leadership. Yogyakarta: Narasi Publisher.

Herusatoto, B. (2008). Simbolism of Java. Yogyakarta: Ombak Publisher.

Mangadeg Foundation. (2010). Wedhatama. Surakarta: Mangadeg Foundation Publisher.

Moertono, S. (1985). State and statecraft in old Java: A study of later Mataram period 16 th to 19th century. 
Jakarta: Obor Indonesia Foundation.

Muhadjir, N. (1996). The qualitative research method. Yogyakarta: Rake Sarasin Publisher.

Santosa, I. B. (2012). Javanese spiritualism: history, ritual, and the essence of teaching. Yogyakarta: Memayu Publishing.

Siswokartono, S. (2006). Sri Mangkunagara IV as a ruler and poetry (1853-1881). Semarang: Aneka Ilmu.

Soeratman, D. (2000). The life of Surakarta palace 1830-1939. Yogyakarta: Obor Indonesia Foundation.

Sumantri, Y. (2005). The wisdom teaching of life of Serat Wedhatama. Yogyakarta: Pustaka Nusatama Foundation.

Suseno, F. M. (1985). Javanese ethics: a philosophical analysis of Javanese life of wisdom. Jakarta: Gramedia Pustaka Utama.

Susilantini, E. (1997). The central concept of KGPAA Mangkunagara IV authorsip. Jakarta: Direktorat Jenderal Kebudayaan.

Yusof, H.M., Kadir, H. A., \& Mahfar, M. (2014). The role of emotions in leadership. Asian Social Science, 10(10), 41-49. http://dx.doi.org/10.5539/ass.v10n10p41.

\section{Copyrights}

Copyright for this article is retained by the author(s), with first publication rights granted to the journal.

This is an open-access article distributed under the terms and conditions of the Creative Commons Attribution license (http://creativecommons.org/licenses/by/4.0/). 